\title{
Genetic diversity and coefficient of kinship among potential genitors for obtaining cultivars of energy cane ${ }^{1}$
}

\author{
Diversidade genética e coeficiente de parentesco entre genitores potenciais para \\ obtenção de cultivares cana energia
}

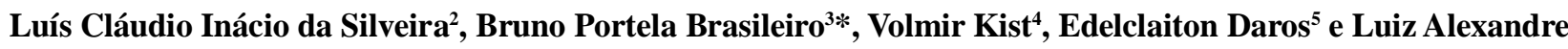 \\ Peternelli ${ }^{3}$
}

\begin{abstract}
The aim of this study was to evaluate the genetic diversity and coefficient of kinship in 50 sugarcane genotypes, in addition to identifying potential parents for obtaining cultivars of energy cane. Diversity analysis was carried out based on the evaluation of morphological and agronomical characteristics. The coefficient of kinship was obtained from information on pedigree. According to analyses carried out, genotypes were separated into two groups. Group G1 consisted of 13 genotypes from the species Saccharum spontaneum and Saccharum robustum. The other 37 genotypes were from back-crosses with Saccharum officinarum, and were allocated to group G2. The genotypes displayed low values for genetic similarity and coefficient of kinship, indicating broad genetic variability in the population. Carrying out crosses involving genotypes from group G1, especially those with a fibre content of over 17\% (IJ76-293, 57NG12, IN84-82, IN84-88, IM76-228 and UM69/001), with genotypes from group G2 which have high stalk yield (RB92579, RB83102, RB047232, RB867515, RB971723, RB937570, RB011941, RB75126, MEX68-200, Co62175 and CP691052), should be explored, with the aim of developing energy cane cultivars. Analyses of diversity and of the coefficient of kinship made it possible to identify two heterotic groups. Moreover, it was possible to identify two potential parent groups for obtaining energy cane cultivars. Genetic distances which are based on both morpho-agronomical data and on pedigree, should be used in a complementary way, with a view to having more information when choosing the best parents.
\end{abstract}

Key words: Saccharum spp. Germplasm. Biomass. Breeding.

RESUMO - O objetivo dessa pesquisa foi avaliar a diversidade genética e a relação de parentesco entre 50 genótipos de canade-açúcar, além de identificar genitores potenciais para a obtenção de cultivares cana energia. A análise de diversidade foi realizada a partir da avaliação de caracteres morfológicos e agronômicos. O coeficiente de parentesco foi obtido a partir das informações de pedigree. De acordo com as análises realizadas os genótipos foram separados em dois grupos. O grupo G1 foi formado por 13 genótipos descendentes das espécies Saccharum spontaneum e Saccharum robustum. Os outros 37 genótipos descendem de retrocruzamentos com Saccharum officinarum e foram alocados no grupo G2. Os genótipos apresentaram baixos valores de similaridade genética e de coeficiente de parentesco, indicando ampla variabilidade genética na população. A condução de cruzamentos envolvendo genótipos do grupo G1, principalmente aqueles com teor de fibra acima de $17 \%$ (IJ76-293, 57NG12, IN84-82, IN84-88, IM76-228 e UM69/001), com os genótipos do grupo G2, que apresentam elevada produtividade de colmos (RB92579, RB83102, RB047232, RB867515, RB971723, RB937570, RB011941, RB75126, MEX68200, Co62175 e CP691052), devem ser explorados com a finalidade de desenvolver cultivares cana energia. As análises de diversidade e do coeficiente de parentesco permitiram a identificação de dois grupos heteróticos. Além disso, foi possível identificar nos dois grupos genitores potenciais para a obtenção de cultivares cana energia. A utilização das distâncias genéticas com base em dados morfo-agronômicos e do pedigree devem ser usadas de forma complementar, visando agregar maior conhecimento na escolha dos melhores genitores.

Palavras-chave: Saccharum spp. Germoplasma. Biomassa. Melhoramento genético.

\footnotetext{
DOI: $10.5935 / 1806-6690.20150015$

* Autor para correspondência

${ }^{1}$ Recebido para publicação em 30/11/2013; aprovado em 08/12/2014

Parte da Tese de Doutorado do primeiro autor apresentada ao Programa de Pós-Graduação em Agronomia/Produção Vegetal da Universidade Federal do Paraná

${ }^{2}$ Departamento de Fitotecnia, Universidade Federal de Viçosa, Viçosa-MG, Brasil, luisufv@ hotmail.com

${ }^{3}$ Departamento de Estatística, Universidade Federal de Viçosa, Viçosa-MG, Brasil, brunobiogene@ hotmail.com, peternelli@ufv.br

${ }^{4}$ Centro de Tecnologia Canavieira, Piracicaba-SP, Brasil, vokist@ gmail.com

${ }^{5}$ Departamento de Fitotecnia e Fitossanitarismo, Universidade Federal do Paraná, Curitiba-PR, Brasil, ededaros@ufpr.br
} 


\section{INTRODUCTION}

Sugarcane (Saccharum spp.) is one of the most efficient crops in the conversion of solar energy into chemical energy (TEW; COBILL, 2008). From the beginning, breeders have taken full advantage of the high potential this crop has for sucrose yield, by means of breeding programs.

In Brazil, the sucrose obtained from sugarcane has been widely used in the production of sugar and ethanol. In turn, the bagasse, traditionally used by power plants only in the cogeneration of electricity, has gained importance in the production of second-generation ethanol (HOFSETZ; SILVA, 2012; RABELO et al., 2011). Recently, with the prohibition on the use of burning for the removal of straw prior to harvesting, other sugarcane residue, such as the leaves and tips (straw), are also gaining importance due to their economic potential (CAPAZ; CARVALHO; NOGUEIRA, 2013; SEABRA et al., 2010).

With the realisation of the feasibility of using straw to produce ethanol (second-generation ethanol) and electricity (combustion), mainly due to the high yield of biomass and low production costs (CARDONA; QUINTERO, PAZ, 2010; DIAS et al., 2013), new lines of research which aim at the development of cultivars with greater fibre content, known as energy cane, are starting to be carried out by different sugarcane breeding programs.

However, as the metabolic pathways for the synthesis of sucrose and fibre are incompatible (MING et al., 2006), the development of energy cane cultivars should include crosses between genotypes of Saccharum spontaneum and Saccharum officinarum. This is because the species $S$. spontaneum has a higher fibre content compared to other species of the genus Saccharum; but its stalk production is low (TEW; COBILL, 2008). On the other hand, the species $S$. officinarum has greater productivity. A combination of these two species would therefore appear to be ideal for the development of cultivars of energy cane.

Appropriate characterisation of the genotypes available in germplasm banks is essential for the selection of genotypes having a potential for use as parents in crosses to generate cultivars of energy cane (BARBOSA et al., 2012; SANTOS et al., 2012).

To this effect, studies into genetic divergence as well as information on pedigree are extremely important for defining the best combinations for crosses between parents (PETERNELLI et al., 2009). Based on pedigree, useful information can be generated, which can be used to prevent crossings of related genotypes, avoiding the effects of endogamic depression (HALLAUER; CARENA; MIRANDA FILHO, 2010).
The aim of this study was to evaluate the genetic diversity and kinship between sugarcane genotypes of the Active Germplasm Bank (AGB) of the InterUniversity Network for the Development of the SugarEnergy Industry (RIDESA), with a view to their use in the development of cultivars of energy cane through reciprocal recurrent selection (RRS).

\section{MATERIAL AND METHODS}

This study evaluated 50 sugarcane genotypes at the ratoon stage, ten months after first harvest (Table 1). The genotypes under evaluation were divided into plots of one row, $3 \mathrm{~m}$ long, spaced $1.4 \mathrm{~m}$ apart, at the AGB of RIDESA, located at the Federal University of Alagoas (UFAL) in the town of Murici, in the state of Alagoas, Brazil, at latitude $9^{\circ} 13$ ' $\mathrm{S}$ and longitude $35^{\circ} 50$ ' $\mathrm{W}$ and an altitude of $450 \mathrm{~m}$ (BARBOSA et al., 2002).

For the 50 genotypes, the following morphological characteristics were evaluated in five stalks per plot: flowering index (FI); flowering (FL); physiological withering (PW); toppling due to development (TD); detrashing (DS); presence of aerial roots (AR); cracks (CR); lateral budding (LB); presence of pilosity (PL); bud prominence $(\mathrm{BP})$; tillering (TL) and growth habit $(\mathrm{GH})$ (Table 2).

Using ten stalks per plot, the agronomical characteristics evaluated were: mean stalk weight (MSW); straw weight (SW); mean stalk diameter (DS) and mean stalk length (SL); juice purity (PUR); fibre content (FIB); cane sucrose content (PC); reducing sugars (RS); total recoverable sugar (TRS) and cane dry weight (DW) (Table 2). The variables PUR, FIB, PC, RS, TRS and DW were obtained from analyses carried out on two samples of $500 \mathrm{~g}$ (chopped cane), using technological analysis methodology (FERNANDES, 2003). Finally, the lignin content of the fibre (LC) was quantified. To this end, samples of dry matter were subjected to NIR analysis (Near Infrared Reflectance).

Analysis of genetic diversity was carried out following the Ward Modified Location Model (WardMLM) (FRANCO et al., 1998), using the phenotypic averages of the quantitative characteristics together with the category modes of the qualitative characteristics evaluated in the 50 sugarcane genotypes. In the WardMLM procedure, genetic distance is estimated using the Gower algorithm (GOWER, 1971). Recently, the WardMLM strategy has been widely used in studies into genetic diversity in sugarcane (BRASILEIRO et al., 2014), the castor bean (OLIVEIRA et al., 2013), the jatropha (BRASILEIRO et al., 2013), the banana (PEREIRA et al., 
2012; PESTANANA et al., 2011) and the common bean (BARBÉ et al., 2009; CABRAL et al., 2010).

Analysis of the coefficient of kinship (CK) was carried out considering all the generations present in the pedigree, which corresponded to 189 known parents over
6 generations. In performing the analysis, the R Software was used (R Development Core Team, 2013), with functions developed by Peternelli et al. (2009), based on expressions presented by Kempthorne (1973), where the coefficient of endogamy is given by (1):

Table 1 - Identification, pedigree, coefficient of endogamy $(F)$ and origin of the 50 genotypes evaluated at the Active Germplasm Bank of RIDESA/UFAL, Brazil

\begin{tabular}{|c|c|c|c|c|}
\hline \multirow{2}{*}{ Genotype } & \multicolumn{2}{|c|}{--------------------Pedigree-------------------- } & \multirow{2}{*}{$\mathrm{F}$} & \multirow{2}{*}{ Origin } \\
\hline & Female Parent & Male Parent & & \\
\hline $57 \mathrm{NG12}$ & S. robustum & $?$ & 0,0000 & Índia \\
\hline C90178 & $?$ & $?$ & 0,0000 & Cuba \\
\hline IJ76-293 & S. robustum & ? & 0,0000 & Java \\
\hline IM76-228 & S. robustum & $?$ & 0,0000 & Indonesia \\
\hline IM76-229 & S. robustum & $?$ & 0,0000 & Indonesia \\
\hline IN84-58 & S. spontaneum & $?$ & 0,0000 & Indonesia \\
\hline IN84-82 & S. spontaneum & $?$ & 0,0000 & Indonesia \\
\hline IN84-88 & S. spontaneum & $?$ & 0,0000 & Indonesia \\
\hline KRAKATAU & S. spontaneum & $?$ & 0,0000 & Indonesia \\
\hline UM69/001 & S. spontaneum & $?$ & 0,0000 & Mauritius \\
\hline US74-103 & L65-69 & SES205A & 0,0000 & USA* \\
\hline US76-14 & NCo310 & TAINAN & 0,0015 & USA \\
\hline US85-1008 & S. spontaneum & US60-313 & 0,0000 & USA \\
\hline B70710 & $28 \mathrm{NG} 288$ & S. spontaneum & 0,0000 & Barbados \\
\hline B74125 & B62118 & $?$ & 0,0000 & Barbados \\
\hline B76734 & BTN143 & SES567 & 0,0000 & Barbados \\
\hline CB38-22 & CP27-139 & $?$ & 0,0000 & Campos Brasil, Brazil \\
\hline $\mathrm{Co} 285$ & STR.MAURITIUS & S. spontaneum & 0,0000 & India \\
\hline Co453 & BLACK CHERIBON & $\mathrm{Co} 285$ & 0,0000 & India \\
\hline Co617 & POJ 2878 & Co285 & 0,0038 & India \\
\hline Co62175 & Co951 & Co419 & 0,0522 & India \\
\hline CP69-1052 & СР62-374 & CP56-59 & 0,0052 & Canal Point, USA \\
\hline CTC5 & SP82-1176 & $?$ & 0,0024 & CTC, Brazil \\
\hline CTC9 & SP81-3491 & $?$ & 0,0000 & CTC, Brazil \\
\hline F150 & $\mathrm{NCo} 310$ & PT43-52 & 0,0015 & Formosa \\
\hline IAC50/134 & Co419 & Co285 & 0,0000 & IAC, Brazil \\
\hline IAC86-2210 & CP52-58 & Co798 & 0,0043 & IAC, Brazil \\
\hline IAC87-3396 & Co740 & SP70-1143 & 0,0039 & IAC, Brazil \\
\hline IANE48-21 & POJ2878 & Co285 & 0,0038 & IAGN, Brazil \\
\hline MEX68-200 & B35187 & Co617 & 0,0008 & Mexico \\
\hline RB011941 & BJ7504 & RB72454 & 0,0001 & RIDESA, Brazil \\
\hline RB01623 & RB835867 & $?$ & 0,0000 & RIDESA, Brazil \\
\hline RB01649 & Co62175 & RB72454 & 0,0173 & RIDESA, Brazil \\
\hline
\end{tabular}


Table 1 Continued

\begin{tabular}{lcccc}
\hline RB0442 & $?$ & $?$ & 0,0000 & RIDESA, Brazil \\
RB047232 & RB865520 & SP91-1049 & 0,0000 & RIDESA, Brazil \\
RB04813 & RB745464 & RB92524 & 0,0000 & RIDESA, Brazil \\
RB04823 & RB931013 & RB72910 & 0,0004 & RIDESA, Brazil \\
RB72910 & $?$ & $?$ & 0,0000 & RIDESA, Brazil \\
RB75126 & C278 & $?$ & 0,0000 & RIDESA, Brazil \\
RB83102 & NA56-79 & SP70-1143 & 0,0002 & RIDESA, Brazil \\
RB867515 & RB72454 & $?$ & 0,0001 & RIDESA, Brazil \\
RB92579 & RB75126 & RB72199 & 0,0000 & RIDESA, Brazil \\
RB928064 & SP70-1143 & $?$ & 0,0000 & RIDESA, Brazil \\
RB93509 & RB72454 & $?$ & 0,0001 & RIDESA, Brazil \\
RB937570 & SP70-1143 & RB72454 & 0,0001 & RIDESA, Brazil \\
RB946022 & RB855511 & RB855077 & 0,0007 & RIDESA, Brazil \\
RB96524 & RB75126 & $?$ & 0,0000 & RIDESA, Brazil \\
RB971723 & H64-1881 & RB8491 & 0,0000 & RIDESA, Brazil \\
RB98710 & SP81-3250 & RB93509 & 0,0007 & RIDESA, Brazil \\
SP81-3250 & CP70-1547 & SP71-1279 & 0,0000 & Copersucar, Brasil \\
\hline
\end{tabular}

"USA = United States of America; CTC = Centro de Tecnologia Canavieira [Centre for Sugarcane Technology]; IAC = Instituto Agronômico de Campinas [Agronomic Institute of Campinas]; RIDESA = Rede Interuniversitária para o Desenvolvimento do Setor Sucroalcooleiro [Inter-University Network for the Developement of the Sugar-Energy Industry]; IANE = Instituto Agrônomo do Nordeste [Agronomic Institute of the Northeast]; Copersucar = Cooperativa de Produtores de Cana-de-Açúcar, Açúcar e Álcool do Estado de São Paulo [Cooperative of Sugarcane, Sugar and Alcohol Producers of the State of Sao Paulo]

Table 2 - Descriptors used to characterise genotypes of the Active Germplasm Bank of RIDESA/UFAL, Brazil

\begin{tabular}{|c|c|c|c|}
\hline Characteristic $^{\mathrm{a}}$ & Category & Characteristic $^{\mathrm{a}}$ & Description \\
\hline FI & $\begin{array}{c}1=\text { Absent, } 2=<30 \%, 3=30 \text { to } 50 \%, 4=> \\
50 \%\end{array}$ & MSW & Mean stalk weight (kg) \\
\hline PW & $1=$ Absent, $2=$ Low, $3=$ Medium, $4=$ High & SW & Weight of straw $(\mathrm{kg})$ \\
\hline $\mathrm{TD}$ & $\begin{array}{c}1=\text { Absent, } 2=<30 \text { o from vertical, } 3=30 \text { to } \\
60^{\circ} \text { from vertical }\end{array}$ & DS & Mean stalk diameter $(\mathrm{cm})$ \\
\hline DS & $1=$ Easy, $2=$ Normal, $3=$ Difficult & SL & Mean stalk length (m) \\
\hline AR & $1=$ Absent, $2=$ Little, $3=$ Normal, $4=$ High & PUR & Juice purity (\%) \\
\hline $\mathrm{CR}$ & $\begin{array}{c}1=\text { Absent, } 2=<20 \%, 3=20 \text { to } 40 \%, 4=> \\
41 \%\end{array}$ & FIB & Fibre content $(\%)$ \\
\hline LB & $1=$ Absent, $2=<20 \%, 3=>20 \%$ & $\mathrm{PC}$ & Cane sucrose content $(\%)$ \\
\hline PL & $1=$ Absent, $2=$ Little, $3=$ Normal, $4=$ High & $\mathrm{RS}$ & Reducing sugars $(\%)$ \\
\hline $\mathrm{BP}$ & $1=1 \mathrm{~mm}, 2=2 \mathrm{~mm}, 3=3 \mathrm{~mm}$ & TRS & Total recoverable sugar $\left(\mathrm{kg} \mathrm{t}^{-1}\right)$ \\
\hline $\mathrm{TL}$ & $1=$ Low, $2=$ Medium $3=$ High & DW & Cane dry weight $(\%)$ \\
\hline $\mathrm{GH}$ & $\begin{array}{c}1=\text { Erect, } 2=\text { Semi-decumbent, } 3= \\
\text { Decumbent }\end{array}$ & $\mathrm{LC}$ & Lignin content $(\%)$ \\
\hline FL & $\begin{array}{c}1=\text { Absent, } 2=\text { Differentiated germ, } 3= \\
\text { Budding phase, } 4=\text { Panicle }\end{array}$ & & \\
\hline
\end{tabular}

${ }^{\mathrm{a}} \mathrm{FI}=$ flowering index $; \mathrm{FL}=$ flowering; $\mathrm{PW}=$ physiological withering; $\mathrm{TD}$ = toppling with development; $\mathrm{DS}=$ detrashing; $\mathrm{AR}=$ presence of aerial roots; $\mathrm{CR}=$ cracks $\mathrm{LB}=$ lateral budding; $\mathrm{PL}=$ presence of pilosity; $\mathrm{BP}=$ bud prominence; $\mathrm{TL}=$ tillering; $\mathrm{GH}=$ growth habit 


$$
F_{x}=\frac{1}{2 k-1}\left[k r_{(A, B)}+\frac{(k+1)}{2}\left(F_{A}+F_{B}\right)\right], k=4
$$

for an octaploid organism, and the coefficient of kinship is (2):

$$
r_{x x}=\frac{1}{2 k}\left[1+(2 k-1) F_{x}\right] \text { and } r_{x y}=r_{(A B, Y)} \frac{1}{2}\left[r_{A Y}+r_{B Y}\right](2)
$$

where: $X$ is the offspring of $A$ and $B$, and $Y$ is any individual of unknown parents.

Clustering of the 50 genotypes was by the UPGMA method (SNEATH; SOKAL, 1973), using the inverse of the kinship matrix $\left(1-\left(2 \times r_{x y}\right)\right)$. Cluster validation was determined with the cophenetic correlation coefficient (CCC) (SOKAL; ROHLF, 1962).

The Pearson correlation between the genetic similarity (GS) (1 - Gower distance) and the coefficient of kinship (CK) was obtained as a way of evaluating the association between the two strategies for estimating genetic variability.

\section{RESULTS AND DISCUSSION}

According to the Ward-MLM analysis, the 50 genotypes were separated into two groups (G1 and G2). Formation of the groups can be seen in the graphical representation of the first two canonical variables (CAN1 and CAN2), which explained $100 \%$ of the observed variation, allowing a clear understanding of the genetic variability among the genotypes under evaluation (Figure 1).

Figure 1 - Distribution of the first two canonical variables (CAN1 and CAN2) showing the formation of two groups (G1 and G2) with the Ward-MLM procedure

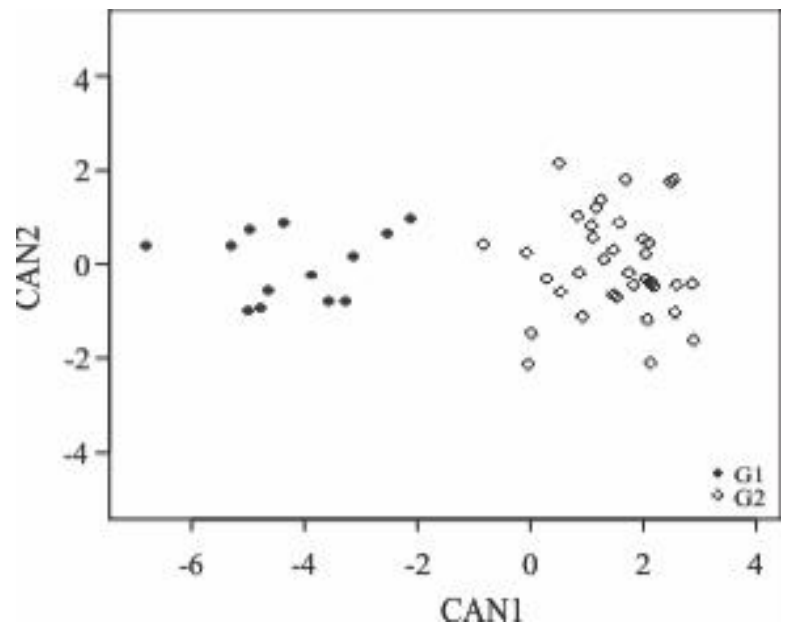

Group G1 consisted of 13 genotypes, while the other 37 genotypes were allocated in group G2 (Table 3). A greater dispersion of genotypes can be seen in group G1 (Figure 1). This may be explained by the fact that the genotypes in this group descend from two species: Saccharum spontaneum and Saccharum robustum. The result had been expected, since these species have high levels of fibre and low sucrose content (Table 3).

Twenty-seven genotypes in group G2 are from Brazilian programs, with 19 of these from RIDESA (Tables 1 and 3). Most of the genotypes of this group are hybrid descendants of biparental crosses between genitors used in different breeding programs in Brazil, especially the cultivars SP70-1143 and RB72454; these two being the genitors respectively of 4 and 5 genotypes (Table 1). The cultivars, SP70-1143 and RB72454 are the principal genitors in the RIDESA breeding program, and of the 78 cultivars released by the program, 17 are the offspring of SP70-1143 and RB72454. Of these 17 cultivars, 10 are descended from crossings between the two principal genitors.

Current sugarcane cultivars were developed from interspecific hybridisation involving $S$. officinarum and $S$. spontaneum, followed by successive backcrosses with $S$. officinarum, in order to develop cultivars with high sugar content, high tillering and a greater tolerance to pests and diseases (TEW; COBILL, 2008). Due to these successive backcrosses, approximately $90 \%$ of the composition of the genome of the $\mathrm{G} 2$ genotypes descends from $S$. officinarum (MING et al., 2006).

Among the quantitative traits evaluated in this study, lignin content (LC) contributed least to the diversity analysis. This can be seen from the correlation of LC with the first canonical variable (CAN1) (Table 4). However, LC is one of the most important characteristics in the generation of electrical energy through combustion (RABELO et al., 2011).

The largest contributions to the diversity analysis were made by mean stalk diameter (DS), mean stalk weight (MSW), fibre content (FIB), cane pol percentage (PC) and straw weight (SW), demonstrating the importance of these characteristics in studies into genetic diversity, and consequently in the choice of parents and crosses that may optimize the development process in varieties of energy cane (Table 4).

The genotypes of group G1 displayed higher mean values relative to $\mathrm{G} 2$, but only for LC, RS and FIB. The mean fibre content of group G1 was higher than the mean value of the principal cultivars currently in use in Brazil (Table 4), especially in genotypes 57NG12 and IM76-228, which showed a fibre content of over $19 \%$. 
Table 3 - Groups and phenotypic averages for the 50 genotypes of the Active Germplasm Bank of RIDESA/UFAL, Brazil

\begin{tabular}{|c|c|c|c|c|c|c|c|c|c|c|c|c|}
\hline Group & Genotype & MSWa & SW & DS & $\mathrm{SL}$ & PUR & FIB & $\mathrm{PC}$ & RS & TRS & DW & LC \\
\hline 1 & $57 \mathrm{NG12}$ & 0.11 & 0.10 & 0.90 & 1.05 & 48.60 & 19.20 & 2.89 & 1.50 & 40.21 & 60.70 & 27.05 \\
\hline 1 & & 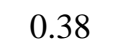 & 20 & & 11 & .00 & .20 & 5.25 & 20 & 46 & 6.40 & 4.16 \\
\hline 1 & IJ76-293 & 35 & 0.40 & 1.60 & 1.73 & 1.40 & 17.20 & 4.45 & 1.30 & 52.84 & & 5.58 \\
\hline 1 & IM76 & 28 & 0.30 & 1.60 & 1.77 & 66.10 & 19.00 & 4.30 & 1.00 & 49.42 & 37.90 & 25.82 \\
\hline 1 & IM76-229 & 0.23 & 0.10 & 1.50 & 1.37 & 66.80 & & 4.36 & 1.10 & & & 25.55 \\
\hline 1 & IN8 & 17 & 0.10 & 1.20 & 1.95 & 79.70 & 16.90 & 6.81 & 0.80 & 71.31 & 40.40 & 27.66 \\
\hline 1 & IN8 & 0.19 & 0.10 & 1.30 & 2.44 & 64.70 & 18.50 & 5.31 & 1.10 & 59.77 & 41.30 & 26.97 \\
\hline 1 & IN84 & 0.18 & 0.10 & 1.10 & 1.68 & 80.60 & 18.50 & 7.98 & 0.80 & 81.48 & 37.00 & 26.05 \\
\hline 1 & KRAKATAU & 0.19 & 0.20 & 1.40 & 1.80 & 75.10 & 16.70 & 4.11 & 1.00 & 47.31 & 22.30 & 23.91 \\
\hline 1 & UM6 & 0.28 & 0.20 & 1.60 & 1.34 & 67.10 & 17.70 & 6.02 & 1.10 & 66.08 & 51.50 & 26.13 \\
\hline 1 & & & 0.10 & 1.60 & 1.26 & & & & 0.90 & & & 2.36 \\
\hline 1 & 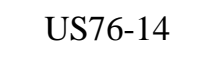 & 0 & 0.10 & 1.10 & 1.23 & 5.60 & 15.40 & 9.39 & 0.70 & 94.17 & 46.70 & 24.27 \\
\hline 1 & 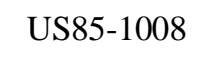 & & 0.10 & & 1. & & & & & & & 40 \\
\hline 2 & B70 & 0.77 & 0.40 & 2.50 & 2.30 & 62.70 & 14.20 & 4.51 & 1.30 & 53.74 & 47.60 & 26.84 \\
\hline 2 & & 1.11 & 0.40 & 3.20 & 1.74 & 75.30 & 15.20 & & 1.00 & 90.43 & 77.80 & 22.23 \\
\hline 2 & B76734 & 0.83 & 0.50 & 2.60 & 1.82 & 92.00 & 12.90 & 10.20 & 0.60 & 101.20 & 48.50 & 23.13 \\
\hline 2 & CB38-22 & 0.60 & 0.50 & 2.70 & 1.65 & 70.50 & 12.90 & 8.65 & 1.10 & 90.81 & 52.00 & 24.17 \\
\hline 2 & C & 0.46 & 0.30 & 1.80 & 1.85 & 84.10 & 14.40 & 10.20 & 0.80 & 102.20 & 45.80 & 26.01 \\
\hline 2 & & 0.65 & 0.30 & 2.40 & 1.74 & 83.40 & 13.80 & 9.90 & 0.80 & 99.76 & 47.60 & 25.80 \\
\hline 2 & & 0.59 & 0.40 & 1.90 & 1.81 & 81.60 & 14.40 & & 0.80 & 96 & 44.20 & 2.83 \\
\hline 2 & Co6 & 1.07 & 0.30 & 3.00 & 1.84 & 85.60 & 12.70 & 12.50 & 0.70 & 123.20 & 49.90 & 24.25 \\
\hline 2 & CP69 & 0.8 & 0.30 & 2.60 & 1.84 & 80.50 & 13.60 & 12.80 & 0.90 & 127.40 & 44.00 & 25.42 \\
\hline 2 & $\mathrm{Cl}$ & 1.05 & 0.40 & 2.40 & 2.29 & 78.20 & 12.30 & 11.50 & 0.90 & 115.90 & 39.50 & 25.11 \\
\hline 2 & & & & & 2.23 & & & & & & & .10 \\
\hline 2 & & 0.80 & 0. & 2.70 & 2.0 & 0 & 12.80 & & 1.00 & & 48.10 & 25.97 \\
\hline 2 & & & & & 2.02 & & & & 0.70 & & & 3.97 \\
\hline 2 & IAC 8 & 0. & 0.30 & 2.80 & 2.01 & 77.40 & 11.80 & 10.10 & 1.00 & 102.60 & 44.30 & 27.45 \\
\hline 2 & IAC 8 & 0.98 & 0.30 & 2.90 & 2.25 & 82.00 & 13.90 & 10.90 & 0.80 & 109.10 & 47.00 & 26.19 \\
\hline 2 & JE 48-21 & 0.65 & 0.30 & 2.40 & 1.50 & & 12.30 & 10.40 & 0.90 & 105.60 & 46.90 & 25.21 \\
\hline 2 & MEX68-200 & 0.94 & 0.30 & 2.70 & 1.89 & 84.30 & 12.90 & 12.30 & 0.80 & 121.80 & 46.60 & 25.90 \\
\hline 2 & & 1.61 & 0.50 & 3.20 & 1.76 & & 12.40 & 10.10 & 1.00 & 103.10 & 55.60 & 23.39 \\
\hline 2 & RB01 & 1.15 & 0.50 & 2.90 & 1.58 & 70.50 & 12.00 & 6.94 & 1.10 & 74.48 & 51.00 & 21.60 \\
\hline 2 & RB01649 & & 0.40 & 2.50 & 1.78 & 80.10 & 12.20 & 11.10 & 0.90 & 112.50 & 58.80 & 23.74 \\
\hline 2 & RB0442 & 0.53 & 0.40 & 2.40 & 1.31 & 79.60 & 12.80 & 8.06 & 0.90 & 83.83 & 49.80 & 21.92 \\
\hline 2 & RB047232 & 0.74 & 0.20 & 2.40 & 1.82 & 81.70 & 9.71 & 12.50 & 0.90 & 125.10 & 48.90 & 26.03 \\
\hline 2 & RB04813 & 0.84 & 0.20 & 2.50 & 1.74 & 78.30 & 14.40 & 10.20 & 0.90 & 103.20 & 63.70 & 23.38 \\
\hline 2 & RB04823 & 0.63 & 0.60 & 2.40 & 1.53 & & 15.60 & 9.16 & 0.90 & 93.69 & 46.00 & 26.77 \\
\hline 2 & RB72910 & 1.23 & 0.60 & 2.80 & 2.54 & 76.00 & 12.10 & 7.90 & 1.00 & 82.87 & 41.80 & 24.77 \\
\hline 2 & & & 0.40 & 3.00 & 1.78 & & 13.20 & & 0.70 & & & 24.17 \\
\hline 2 & RB83102 & 0.78 & 0.30 & 2.80 & 1.66 & 84.00 & 13.80 & 12.20 & 0.80 & 121.20 & 46.10 & 24.66 \\
\hline 2 & RB867515 & 1.40 & 0.40 & 2.90 & 2.57 & 82.70 & 15.70 & 12.40 & 0.80 & 123.00 & 57.10 & 24.41 \\
\hline
\end{tabular}


Table 3 Continued

\begin{tabular}{rcrrrrrrrrrrr}
\hline 2 & RB92579 & 1.10 & 0.40 & 2.70 & 2.14 & 86.40 & 14.30 & 13.00 & 0.70 & 127.70 & 52.20 & 24.14 \\
2 & RB928064 & 1.20 & 0.30 & 2.70 & 1.91 & 82.90 & 12.20 & 9.79 & 0.80 & 98.77 & 48.80 & 25.04 \\
2 & RB93509 & 0.95 & 0.30 & 2.90 & 1.80 & 68.00 & 12.30 & 9.36 & 1.20 & 98.39 & 34.10 & 23.84 \\
2 & RB937570 & 1.16 & 0.50 & 3.00 & 1.86 & 92.10 & 13.80 & 11.70 & 0.60 & 114.70 & 54.10 & 24.61 \\
2 & RB946022 & 1.10 & 0.40 & 2.70 & 1.83 & 80.10 & 14.30 & 10.50 & 0.90 & 106.00 & 51.60 & 26.17 \\
2 & RB96524 & 0.84 & 0.40 & 2.70 & 1.62 & 68.60 & 12.40 & 7.50 & 1.20 & 80.65 & 50.90 & 24.82 \\
2 & RB971723 & 1.37 & 0.50 & 2.80 & 2.37 & 82.30 & 13.20 & 11.50 & 0.80 & 115.20 & 54.00 & 24.02 \\
2 & RB98710 & 0.84 & 0.40 & 2.80 & 1.84 & 83.80 & 13.10 & 11.30 & 0.80 & 112.30 & 42.40 & 26.27 \\
2 & SP81-3250 & 1.19 & 0.40 & 2.60 & 2.34 & 71.90 & 13.30 & 9.54 & 1.10 & 98.93 & 45.60 & 25.78 \\
\hline
\end{tabular}

${ }^{\mathrm{a}} \mathrm{MSW}=$ mean stalk weight $(\mathrm{Kg}) ; \mathrm{SW}=$ mean straw weight $(\mathrm{Kg}) ; \mathrm{DS}=$ mean stalk diameter $(\mathrm{cm}) ; \mathrm{SL}=$ mean stalk length $(\mathrm{m}) ; \mathrm{PUR}=$ juice purity $(\%)$; $\mathrm{FIB}=$ fibre content $(\%) ; \mathrm{PC}=$ cane sucrose content $(\%) ; \mathrm{RS}=$ reducing sugars $(\%) ; \mathrm{TRS}=$ total recoverable sugar $\left(\mathrm{kg} \mathrm{t}^{-1}\right.$ cane $) ; \mathrm{DW}=$ cane dry weight $(\%) ; \mathrm{LC}=$ lignin content $(\%)$

Table 4 - Mean values, standard deviation (SD), maximum and minimum values for the quantitative characteristics of both groups (G1 and G2), and the correlation coefficient of the characteristics with the first canonical variable (CAN1)

\begin{tabular}{|c|c|c|c|c|c|c|c|}
\hline \multirow{2}{*}{ Variables $^{\mathrm{a}}$} & \multicolumn{3}{|c|}{-----------------Group (G1)------------------- } & \multicolumn{3}{|c|}{ 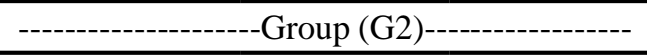 } & \multirow{2}{*}{ CAN1 ${ }^{\mathrm{b}}$} \\
\hline & Mean \pm SD & Max. & Min. & Mean \pm SD & Max. & Min. & \\
\hline MSW & $0.22 \pm 0.08$ & 0.38 & 0.11 & $0.92 \pm 0.27$ & 1.61 & 0.46 & 0.85 \\
\hline SW & $0.16 \pm 0.07$ & 0.36 & 0.06 & $0.37 \pm 0.09$ & 0.57 & 0.17 & 0.75 \\
\hline DS & $1.39 \pm 0.31$ & 2.09 & 0.88 & $2.64 \pm 0.30$ & 3.24 & 1.81 & 0.94 \\
\hline SL & $1.60 \pm 0.41$ & 2.44 & 1.05 & $1.90 \pm 0.29$ & 2.57 & 1.31 & 0.41 \\
\hline PUR & $70.29 \pm 9.76$ & 85.61 & 48.55 & $79.77 \pm 6.38$ & 92.13 & 62.73 & 0.53 \\
\hline FIB & $16.73 \pm 1.82$ & 19.24 & 14.20 & $13.26 \pm 1.18$ & 15.73 & 9.71 & -0.80 \\
\hline $\mathrm{PC}$ & $5.94 \pm 2.17$ & 10.32 & 2.89 & $10.21 \pm 1.79$ & 12.96 & 4.51 & 0.76 \\
\hline RS & $1.03 \pm 0.20$ & 1.47 & 0.70 & $0.88 \pm 0.15$ & 1.29 & 0.55 & -0.40 \\
\hline TRS & $64.87 \pm 18.95$ & 104.70 & 40.21 & $103.54 \pm 15.86$ & 127.66 & 53.74 & 0.77 \\
\hline DW & $42.41 \pm 10.19$ & 60.70 & 22.29 & $49.22 \pm 7.25$ & 77.82 & 34.14 & 0.37 \\
\hline $\mathrm{LC}$ & $25.45 \pm 1.46$ & 27.66 & 22.36 & $24.67 \pm 1.41$ & 27.45 & 21.60 & -0.25 \\
\hline
\end{tabular}

${ }^{\mathrm{a}} \mathrm{MSW}=$ mean stalk weight $(\mathrm{Kg}) ; \mathrm{SW}=$ mean straw weight $(\mathrm{Kg}) ; \mathrm{DS}=$ mean stalk diameter $(\mathrm{cm}) ; \mathrm{SL}=$ mean stalk length (m); PUR = juice purity $(\%)$; $\mathrm{FIB}=$ fibre content $(\%) ; \mathrm{PC}=$ cane sucrose content $(\%) ; \mathrm{RS}=$ reducing sugars $(\%) ; \mathrm{TRS}=$ total recoverable sugar $\left(\mathrm{kg} \mathrm{t}^{-1}\right.$ cane $) ; \mathrm{DW}=$ cane dry weight $(\%) ; \mathrm{LC}=$ lignin content $(\%) ;{ }^{\mathrm{b}} \mathrm{CAN} 1=$ first canonical variable

In both groups, the predominant genotypes are those of erect growth habit, high flowering index and expanded panicles, as well as the absence of toppling, cracks, aerial roots and pilosity (Table 5).

All the genotypes of group G1 display flowering at the expanded-panicle stage and a high level of withering; both undesirable characteristics in commercial crops. However, it should be remembered that the genotypes were evaluated at the RIDESA breeding station, where the climatic conditions favour flowering in sugarcane (BARBOSA et al., 2002). A germ with a thickness of less than, or equal to $1 \mathrm{~mm}$, high tillering, difficult detrashing and stalks without lateral budding are also notable characteristics of this group. In group G2, most genotypes have a lower fibre content and higher sucrose levels, as well as a germ of approximately $2 \mathrm{~mm}$, medium tillering, normal detrashing and stalks with little lateral budding (Table 5).

To increase the probability of obtaining superior genotypes, carrying out crosses of contrasting parents is recommended (HALLAUER; CARENA; MIRANDA FILHO, 2010), it being essential to take the degree 
Table 5 - Number of genotypes for each category of morphological characteristics in the two groups (G1 and G2) formed following the Ward-MLM strategy

\begin{tabular}{|c|c|c|c|c|c|}
\hline \multirow{2}{*}{ Caracteristic } & \multicolumn{2}{|c|}{ 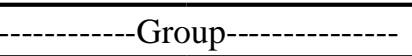 } & \multirow{2}{*}{ Caracteristic } & \multicolumn{2}{|c|}{----------Group-------------- } \\
\hline & G1 & $\mathrm{G} 2$ & & G1 & $\mathrm{G} 2$ \\
\hline Flowering index & & & Cracks & & \\
\hline absent & 0 & 4 & Absent & 11 & 26 \\
\hline reduced & 1 & 1 & Little & 2 & 6 \\
\hline normal & 2 & 3 & Normal & 0 & 4 \\
\hline high & 10 & 29 & High & 0 & 1 \\
\hline Flowering & & & Lateral budding & & \\
\hline absent & 0 & 3 & Absent & 8 & 15 \\
\hline differentiated germ & 0 & 3 & Little & 5 & 20 \\
\hline budding phase & 0 & 4 & abundant & 0 & 2 \\
\hline expanded panicle & 13 & 27 & Pilosity & & \\
\hline Withering & & & Absent & 6 & 17 \\
\hline absent & 0 & 8 & Little & 0 & 11 \\
\hline low & 0 & 12 & Médium & 2 & 7 \\
\hline medium & 0 & 9 & High & 5 & 2 \\
\hline high & 13 & 8 & Bud prominence & & \\
\hline Toppling & & & $1 \mathrm{~mm}$ & 9 & 14 \\
\hline absent & 8 & 23 & $2 \mathrm{~mm}$ & 4 & 16 \\
\hline inclination less than $30^{\circ}$ & 5 & 13 & $3 \mathrm{~mm}$ & 0 & 7 \\
\hline between $30^{\circ}$ and $60^{\circ}$ & 0 & 1 & Tillering & & \\
\hline Detrashing & & & Low & 1 & 5 \\
\hline easy & 0 & 4 & Médium & 1 & 24 \\
\hline normal & 1 & 20 & High & 11 & 8 \\
\hline difficult & 12 & 13 & Growth habit & & \\
\hline Aerial roots & & & Erect & 8 & 26 \\
\hline absent & 7 & 33 & semi-decumbent & 5 & 11 \\
\hline few & 6 & 4 & decumbent & 0 & 0 \\
\hline
\end{tabular}

of kinship between parents into consideration. The UPGMA method of grouping (SNEATH; SOKAL, 1973), using the kinship matrix obtained from the pedigree data, contributed in identifying the relationship between genotypes (Figure 2).

The correlation between the cophenetic matrix of the UPGMA hierarchical clustering and the inverse of the kinship matrix was satisfactory (cophenetic correlation coefficient $=0.88$ ), with little distortion of the generated graph (Figure 2).

In the dendrogram, only genotypes C90178, US74103 and US76-14 were not located close to the other genotypes of group G1 (Figure 2). This was due to a lack of information on the genitors of genotype C90178, and because genotypes US74-103 and US76-14 are directly descended from $S$. robustum or S. espontaneum (Table 1). However, the close relationship of these genotypes with group G1, as seen from the morphological and agronomical characteristics under evaluation, suggests that their parents were descendants of S. spontaneum or S. robustum.

The Pearson correlation coefficient (r) between genetic similarity (GS) and the coefficient of kinship (CK) was only 0.08 , demonstrating the low association between the two strategies for estimating genetic variability (Figure 3). 
Figure 2 - Dendrogram generated using the UPGMA method from the inverse of the kinship matrix $\left(1-\left(2 \times r_{x y}\right)\right)$ between 50 genotypes of the Active Germplasm Bank of UFAL/RIDESA (cophenetic correlation coefficient $=0.88$ )

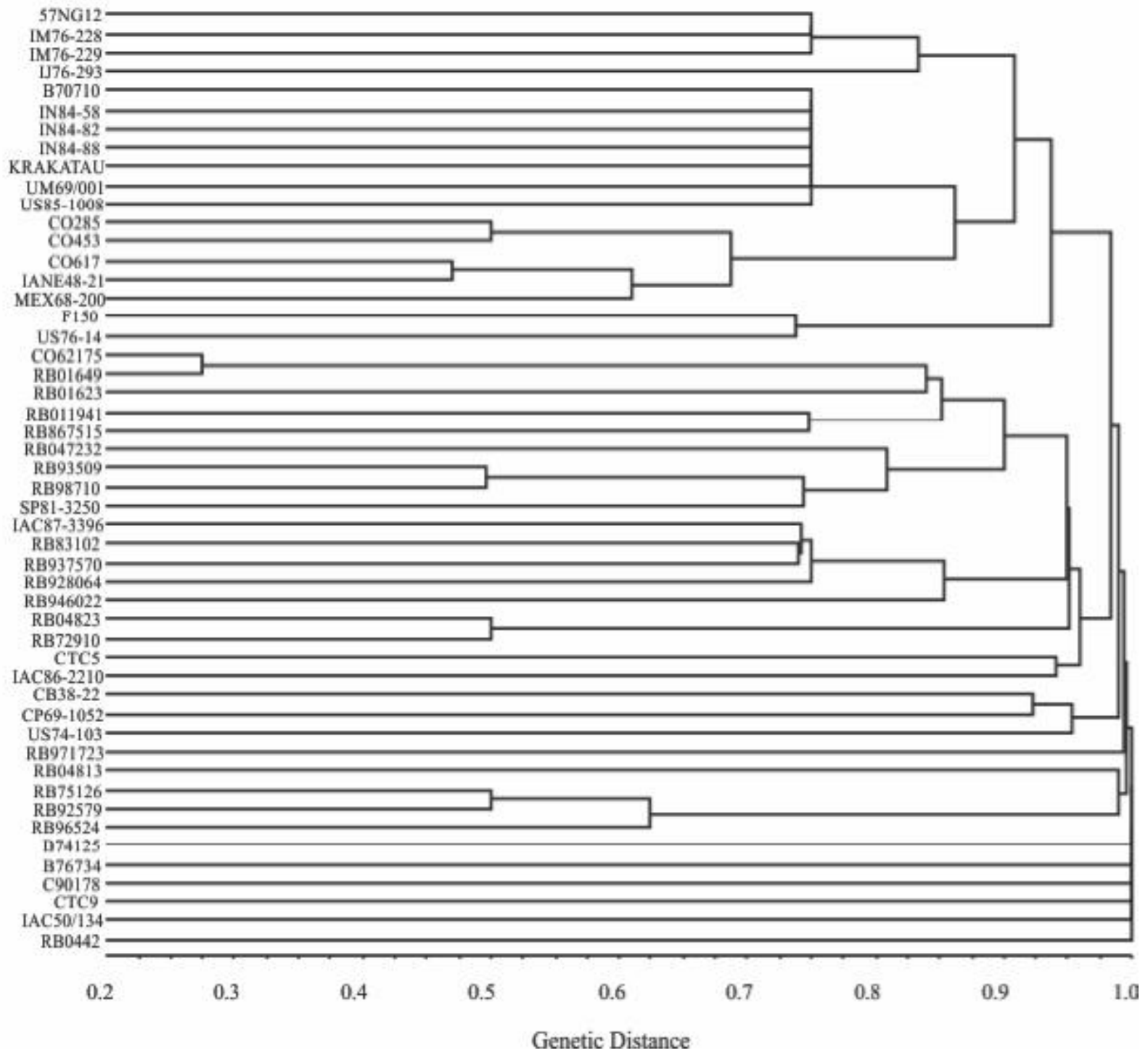

The low correlation between GS and CK in sugarcane was also observed by Lima et al. (2002). Although these authors used data from AFLP markers, the correlation found between GS and CK was only 0.42. Duarte Filho et al. (2010) also found a low correlation between $\mathrm{GS}$ and $\mathrm{CK}(\mathrm{r}=0.17)$ when evaluating sugarcane genotypes using data from SSR markers. These results confirm the need for further use of differing analyses of genetic diversity, so as to have increasing knowledge of the germplasm which is available to sugar-cane breeding programs.

While most of the values for genetic similarity (GS) were between 0.3 and 0.6 , the majority of the coefficients of kinship (CK) were between 0 and 0.2 (Figure 3). These figures show the existence of genetic variability among the genotypes involved in this study, which can be exploited in breeding programs. However, it is noteworthy that low values for CK may in part be related to a lack of information on the genealogy of some genotypes (Table 1). On the other hand, it should be considered that sugarcane is octaploid by nature, which makes numerous allelic combinations possible at a single locus during fertilisation. As a result, there is great phenotypic variability among the descendants of crosses between contrasting parents. In many ways this was evident in the results obtained wih this study. Of all the possible combinations of genotype pairs $(1,225)$, in only ten was the value for CK greater than 0.4 (Figure 3). The only relatively high value $(0.72)$ was observed 
Figure 3 - Plot of the correlation between kinship coefficient $(2$ $\mathrm{x}_{\mathrm{xy}}$ ) and genetic similarity (1 - Gower distance) among 1,225 pairs of sugarcane genotypes

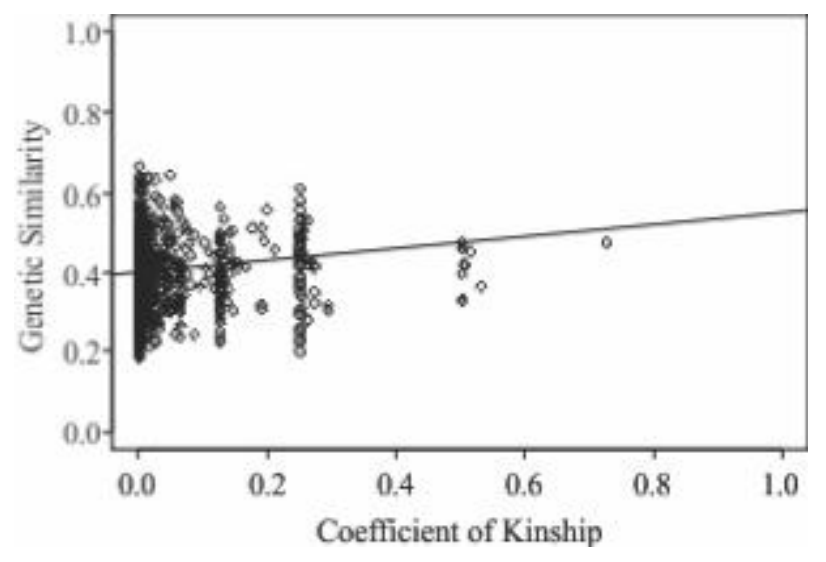

between a female parent (Co62175) and the female offspring (RB01649). The coefficient of endogamy was also low in all genotypes, varying between 0 and 0.05 (Table 1), showing the high heterozygosity of the sugarcane genotypes evaluated.

According to Tew and Cobill (2008), sugarcane currently being cultivated has approximately $12 \%$ fibre, $13 \%$ sugar and $75 \%$ water. According to the same authors, breeding programs for obtaining energy cane should be aiming to develop cultivars with $30 \%$ fibre, $5 \%$ sugar and $65 \%$ water. It should be remembered that the road to achieving genotypes with these characteristics is relatively long. Moreover, considering that production plants are not yet ready to process sugarcane with a fibre content of over $20 \%$, the development of cultivars with a fibre content of around $17 \%$ and which maintain approximately $13 \%$ sugar, would answer the current needs of the sugarenergy industry. This type of cane would increase the capacity for biomass production by increasing the percentage of fibre, without resulting in losses in sugar production.

Carrying out crosses involving genotypes from group G1, particularly those with a fibre content of more than $17 \%$ (IJ76-293, 57NG12, IN84-82, IN84-88, IM76-228 and UM69 / 001), with genotypes of group G2 which display high stalk productivity (RB92579, RB83102, RB047232, RB867515, RB971723, RB937570, RB011941, RB75126, MEX68-200, Co62175 and CP691052) (Table 3), as well as crosses between the best genotypes within each group, should be explored with the aim of developing energy cane cultivars by means of reciprocal recurrent selection (RRS).

\section{CONCLUSIONS}

1. Analyses of diversity and of the coefficient of kinship identified two heterotic groups of potential genitors of energy cane cultivars;

2. The use of genetic distances based on morphoagronomic and pedigree data, should be used in a complementary way to obtain greater knowledge on potential genitors for the generation of energy cane cultivars.

\section{ACKNOWLEDGEMENTS}

The authors wish to thank CAPES and CNPq for their financial support.

\section{REFERENCES}

BARBÉ, T. C. et al. Association between advanced generations and genealogy in inbred lines of snap bean by the Ward-Modified Location Model. Euphytica, v. 173, n. 3, p. 337-343, 2009.

BARBOSA, M. H. P. et al. Genetic improvement of sugarcane for bioenergy: the Brazilian experience in network research with RIDESA. Crop Breeding and Applied Biotechnology, v. 12, n. 2, p. 87-98, 2012.

BARBOSA, G. V. S. et al. A brief report on sugarcane breeding program in Alagoas, Brazil. Crop Breeding and Applied Biotechnology, v.2, n. 4, p. 613-616, 2002.

BRASILEIRO, B. P. et al. Genetic diversity in sugarcane varieties in Brazil based on the Ward-Modified Location Model clustering strategy. Genetics and Molecular Research, v. 13, n. 1, p. 1650-1660, 2014.

BRASILEIRO, B. P. et al. Genetic diversity and selection gain in the physic nut (Jatropha curcas). Genetic and Molecular Research, v. 12, n. 3, p. 2341-2350, 2013.

CABRAL, P. D. S. et al. Quantification of the diversity among common bean accessions using Ward-MLM strategy. Pesquisa Agropecuária Brasileira, v. 45, n. 10, p. 1124$1132,2010$.

CAPAZ, R. S.; CARVALHO, V. S. B.; NOGUEIRA, L. A. H. Impact of mechanization and previous burning reduction on GHG emissions of sugarcane harvesting operations in Brazil. Applied Energy, v. 102, p. 220-228, 2013.

CARDONA, C. A.; QUINTERO, J. A.; PAZ, I. C. Production of bioethanol from sugarcane bagasse: status and perspectives. Bioresource Technology, v. 101, n. 13, p. 4754-4766, 2010.

DIAS, M. O. S. et al. Cogeneration in integrated first and second generation ethanol from sugarcane. Chemical Engineering Research and Design, v. 91, n. 8, p.1411-1417, 2013. 
DUARTE FILHO, L. S. C et al. Genetic similarity among genotypes of sugarcane estimated by SSR and coefficient of parentage. Sugar Tech, v. 12, n. 2, p. 145-149, 2010.

FERNANDES, A. C. Cálculos na agroindústria da cana-deaçúcar. Piracicaba: STAB, 2003. 193 p.

FRANCO J. et al. Classifying genetic resources by categorical and continuous variables. Crop Science, v. 38, n. 6, p. 16881696,1998

GOWER, J. C. A general coefficient of similarity and some of its properties. Biometrics, v. 27, n. 04, p. 857-871, 1971.

HALLAUER, A. R.; CARENA, M. J.; MIRANDA FILHO, J. B. Quantitative Genetics in Maize Breeding. New York: Springer, 2010. 663 p.

HOFSETZ, K.; SILVA, M. A. Brazilian sugarcane bagasse: Energy and non-energy consumption. Biomass and Bioenergy, v. 46, p. 564-573, 2012.

KEMPTHORNE O. An introduction to genetic statistics. Ames: Iowa State University Press, 1973. 545p.

LIMA, M. L. A. et al. Analysis of genetic similarity detected by AFLP and coefficient of parentage among genotypes of sugar cane (Saccharum spp.). Theoretical and Applied Genetics, v. 104, n. 1, p. 30-38, 2002.

MING R. et al. Sugarcane Improvement through Breeding and Biotechnology. In: JANICK, J. Plant breeding reviews. New York, John Wiley \& Sons, 2006. cap. 2, p. 15-118.

OLIVEIRA, R. S. et al. Genetic divergence on castor bean using the ward-mlm strategy. Revista Ciência Agronômica, v. 44 , n. 3 , p. $564-570,2013$.

PEREIRA, V. M. et al. Genetic diversity between improved banana diploids using canonical variables and the WardMLM method. Pesquisa Agropecuária Brasileira, v. 47, n. 10, p. 1480-1488, 2012.
PESTANANA, R. K. N et al. Agronomic and molecular characterization of gamma ray induced banana (Musa sp.) mutants using a multivariate statistical algorithm. Euphytica, v. 178, n. 2, p. 151-158, 2011.

PETERNELli, L. A. et al. Análise dos coeficientes de endogamia e de parentesco para qualquer nível de ploidia usando o pacote estatístico R. Bragantia, v. 68, n. 4, p. 849$855,2009$.

R DEVELOPMENT CORE TEAM (2013) R: A language and environment for statistical computing. $\mathrm{R}$ Foundation for Statistical Computing, Vienna, Austria. ISBN 3-900051-07-0, Available at < http://www.R-project.org/> Assessed in: April 2013.

RABELO, S. C. et al. Production of bioethanol, methane and heat from sugarcane bagasse in a biorefinery concept. Bioresource Technology, v. 102, n. 17, p. 7887-7895, 2011.

SANTOS, J. M. et al. Genetic diversity of the main progenitors of sugarcane from the RIDESA germplasm bank using SSR markers. Industrial Crops Products, v. 40, p. 145-150, 2012.

SEABRA, J. E. A. et al. A techno-economic evaluation of the effects of centralized cellulosic ethanol and co-products refinery options with sugarcane mill clustering. Biomass and Bioenergy, v. 34 , n. 8 , p. $1065-1078,2010$.

SNEATH, P. H.; SOKAL, R. R. Numerical taxonomy: The principles and practice of numerical classification. San Francisco: W.H. Freeman, 1973. 573 p.

SOKAL, R. R.; ROHLF, F. J. The comparison of dendrograms by objective methods. Taxon. v.11, n. 02, p. 33-40, 1962.

TEW, T. L.; COBILL, R. M. Genetic Improvement of Sugarcane (Saccharum spp.) as an Energy Crop. In: VERMERRIS, W. Genetic Improvement of Bioenergy Crops. Springer, New York, 2008. cap. 9, p. 273-294. 